\title{
Effect of Styles and Leadership Work Discipline to Employee Performance (Case Study of PT. Telecommunication Indonesia Tbk Dki Jakarta)
}

\section{Ryani D. Parashakti, Agustinus Haryadi, and Muhammad Nashar}

Universitas Mercu Buana

\section{Abstract}

This study aims to determine the effect of leadership style and work discipline on employee performance. The subject of this research is employees of PT. Telecommunication Indonesia, Tbk DKI Jakarta. This research was conducted on 145 respondents by using quantitative descriptive approach. Therefore, the data analysis used is statistical analysis in the form of multiple linear regression tests.

Corresponding Author: Muhammad Nashar muhammad_nashar@ mercubuana.ac.id

Received: 29 August 2018 Accepted: 18 September 2018 Published: 11 November 2018

Publishing services provided by Knowledge $\mathrm{E}$

(c) Ryani D. Parashakti et al. This article is distributed under the terms of the

Attribution License, which permits unrestricted use and redistribution provided that the original author and source are credited.

Selection and Peer-review under the responsibility of the ICOI-2018 Conference Committee.

\section{G OPEN ACCESS}

\section{Introduction}

Human resources is one important factor in the company. According Syamsuddinnor (2014), human resources is one of the main capital in an organization, which can provide an invaluable contribution in the strategy of achieving organizational goals. One example of the importance of the contribution of human resources in a company can be seen from the production process. Where when the company already has a strong financial, raw materials are met, and the latest technology but the lack of good human resources, then the production process will not run smoothly.

This shows the more obvious that the position of human resources in the company is an important asset that must be managed properly and properly. As Ruyatnasih (2013) discloses, human resources are one of the company's assets and one of the important factors for realizing the company's goals. Like other company assets, human resources 
also have a dominant role in companies that can realize the goals of the company, then it is proper that human resources are maintained like other company's assets.

Good human resources management and correct is a management that can improve employee performance so that it can realize the company's goals. According to Eman (2012), human resources management is a science or how to manage the relationship and role of resources owned by individuals efficiently and effectively and can be used maximally so as to achieve the goals of the company or organization, employees, and society to the maximum.

PT. Telecommunication Indonesia, Tbk is a BUMN engaged in telecommunication services and network services in the territory of Indonesia and therefore subject to the laws and regulations applicable in this Country. With its status as a state-owned company whose shares are traded on the stock exchange, TELKOM's majority shareholder is the Government of the Republic of Indonesia while the rest is controlled by the public.

Human resources TELKOM is a very important asset for the company. Therefore, TELKOM changed its perspective on human resources as Human Capital. TELKOM's human resource development strategy emphasizes the harmonization of human resource competency in line with TELKOM Group's business portfolio which focuses more on Telecommunication, information, multimedia, and edutainment.

Table 1 is the result of a pre-survey on 10 employees who are at PT. Telecommunication, Tbk Jakarta.

TABLE 1: Pre-survey questionnaire.

\begin{tabular}{l|l|c|c|}
\hline No. & Question & Yes & No \\
\hline 1 & I always feel satisfied working here & $100 \%$ & $0 \%$ \\
\hline 2 & My Boss gives me spirit to staffs to have better performance & $10 \%$ & $90 \%$ \\
\hline 3 & I always feel enthusiastic to do job & 20 & 80 \\
\hline 4 & I feel insurance, salary, etc., are sufficient & 100 & 0 \\
\hline 5 & I feel that I have ability to do job & 30 & 70 \\
\hline Source: & The results of pre-survey on 10 employees in PT. Telecommunication, Tbk Jakarta.
\end{tabular}

From Table 1, it can be seen a phenomenon that occurs in PT. Telecommunication Indonesia, Tbk is a leadership style that is not appropriately applied to employees, which is related to control and supervision of the leadership so that no one directs employees at work. So employees tend to come late to work and do not enter for reasons that are less clear. 
The data in PT. Telecommunication Indonesia, Tbk is the employees tend to be late and high absence every month. This is obtained from the standard of absenteeism and absence of employees is $4 \%$ on each month.

Employee discipline in PT. Telecommunication Indonesia, Tbk is also a cause of nonoptimal performance that is marked by the settlement of client complaints against telecommunications services that are not timely in the settlement, because employees who are in the field cannot be closely monitored, employees who are not in accordance with the break time that has been determined company, resulting in ineffective and efficient employee performance from data the total number of all employees in DGS (Government Service Division) PT. Telecommunication Indonesia, Tbk is 228 employees with employee performance below the standard of each segment/unit.

Based on the comparison of the aforementioned studies about the style of leadership, work discipline on employee performance is very interesting to conduct research with the title 'The Influence of Leadership Style and Work Discipline on Employee Performance at PT. Telecommunication Indonesia, Tbk Jakarta'.

\subsection{Formulation of the problem}

Based on the aforementioned description, then the problem of problems that exist in the research can be formulated as follows:

1. Does the style of leadership affect the performance of employees of PT. Telecommunication Indonesia, Tbk?

2. Does work discipline affect the performance of employees of PT. Telecommunication Indonesia, Tbk?

\subsection{Research purposes}

The purpose of the study include:

1. To know and analyze the influence of leadership style on employee performance of PT. Telecommunication Indonesia, Tbk

2. To know and analyze the influence of discipline on employee performance of PT. Telecommunication Indonesia, Tbk 


\section{Literature Review}

According to Rivai (2010), Human Resource Management is one of the areas of general management covering aspects of planning, organizing, implementing, and controlling. Leadership Style According Sutrisno (2011) The style of leadership is a process of one's activities to move others by leading, guiding, influencing others, to do something to achieve the expected results. Work Discipline According to Singodimedjo (2013), states that discipline is the attitude of dosage and willingness of a person to obey and obey the norms of regulations that apply around Employee performance According to Rivai (2013), performance is a real behavior that is displayed every person as a work performance generated by employees in accordance with its role in the company.

\section{Logical framework}

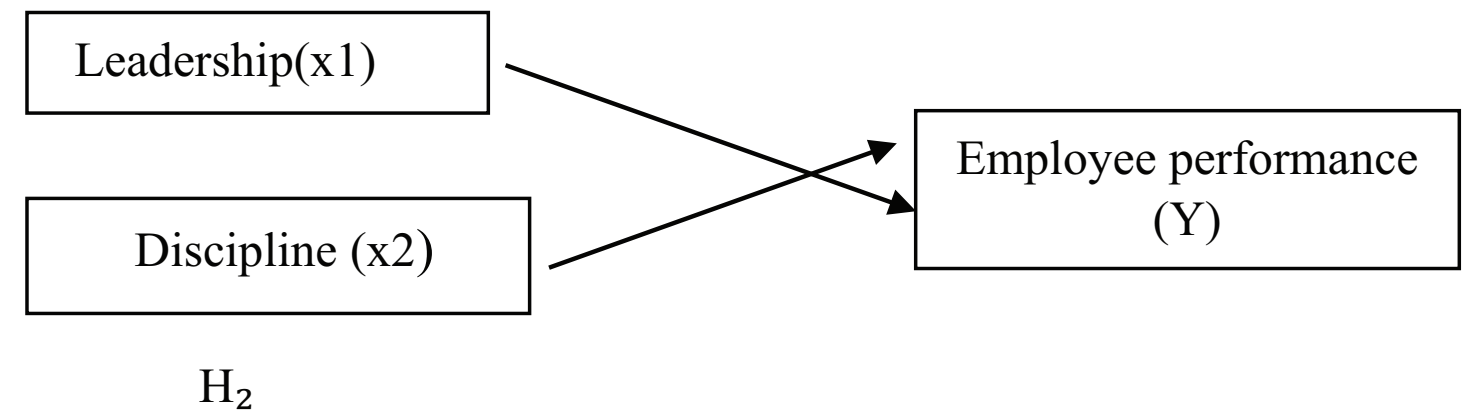

Information:

$\mathrm{X}_{1}$ : Leadership Style

$\mathrm{X}_{2}$ : Work Discipline

Y: Employee Performance

\section{Hypothesis}

H1: Leadership style positively affects the performance of employees of PT. Telecommunication Indonesia, Tbk.

H2: Work discipline has a positive effect on the performance of employees of PT. Telecommunication Indonesia, Tbk. 


\section{Research Methods}

The research design used in this research is qualitative research. In this study, the population is the employee of PT. Telecommunication Indonesia Tbk number of 228 people. To obtain a sample of 145 employees from that population, this technique is used, using the Slovin formula method.

$$
n=N /(1+N e 2)
$$

Information

$$
\begin{aligned}
& \mathrm{n}=\text { number of samples } \\
& \mathrm{N}=\text { total population } \\
& \mathrm{e}=\text { error tolerance }
\end{aligned}
$$

In this study will conduct research on the population of 228 employees, using $95 \%$ accuracy and $5 \%$ error tolerance.

Answer:

95\% accuracy, $5 \%$ error tolerance

$\mathrm{n}=\mathrm{N} /(1+\mathrm{Ne} 2)$

$n=228 /(1+228 .(0,05) 2)$

$n=145.22$

$n=145$ sample objects

- So it can be concluded that the samples taken for this study using the Slovin's formula amounted to 145 employees of 228 population.

\section{Results and Discussion}

\subsection{Instrument test results}

\subsubsection{Validity test results}

Test validity is the determination or accuracy of an instrument in measuring what you want measured. Because the number of respondents used for the validity test is 145 employee,

Based on the $t$-test all the questions for the independent variables of leadership style is valid. This is shown because r count must be $>$ from r table. $R$ table used is 0.1371 (see table r with DF 143, 5\% significance, one tailed). 


\subsubsection{Validity test results against the items of variables discipline work statement}

Next to see the validity of all the questions that represent the independent variables of Work Discipline

Based on the test that all the questions for the independent variable of work discipline are valid. This is shown because $r$ count (see corrected item-total correlation column) > r table. $R$ table used is 0.1371 (see table $r$ with $d f 143,5 \%$ significance, one tailed)

\subsubsection{Validity test results against the statement items employee performance variables}

Next test the validity of Employee Performance variables performed on 145 respondents with the number of indicators as many as 17 questions.

Based on the test that all the questions for the independent variable of work discipline are valid. This is shown because r count (see corrected item-total correlation column) > r table. $r$ table used is 0.1371 (see table $r$ with $d f 143,5 \%$ significance, one tailed).

\subsection{Test reliability}

The reliability test is a measure of the internal consistency of the indicators of a construct showing the degree to which each indicator indicates a common latent construct/factor. In other words, the tool has consistent results when used many times at different times in this study, the requirement of a reliable or reliable questionnaire is if the value of Cronbach's alpho $>0.06$. The results of the reliability test of leadership style variables, work discipline, and employee performance using the SPSS 23 program.

\subsubsection{Reliability test results variable leadership style}

Based on the output results can be seen the reliability value of the independent variables leadership style obtained the result that the coefficient of leadership style variable reliability in this study showed the value of Cronbach's alpha 0.755 so it can be said that the leadership style variable declared reliable because $>0.60$. 


\subsubsection{Reliability test results variable work discipline}

Based on test, the results obtained that the coefficient of variable reliability of work discipline in this study showed the value of Cronbach's alpha 0.782 so it can be said that leadership style variables declared reliable because $>0.60$.

\subsubsection{Reliability test results employee performance variables}

Reliability test results using SPSS version 23 program assistance obtained results that the coefficient of reliability variable employee performance in this study showed the value of Cronbach's alpha 0.827 so it can be said that leadership style variables declared reliable because $>0.60$.

\subsection{Classic assumption test}

\subsubsection{Normality test results}

Normality test has a purpose to test whether in regression model, annoying or residual variable has normal distribution. As it is known that the $T$ and $F$ tests assume that the residual values follow the normal distribution. To detect the residual normality can also be done by Kolmogorov-Smirnov test. The results of normality residual test in this study was found that the residual normality test results with Kolmogorov-Smirnov probability significance of 1.382 generated by the overall result is greater than $\alpha=0.05$. So, it can be concluded that the data is normally distributed and the regression model has met the assumption of normality.

\subsubsection{Multicollinearity test results}

Multicollinearity test is a test shown to test whether the regression model found the existence of collation between independent variables (independent variables). Good regression test model should not occur multicollinearities. The results of multicollinearity test data processing using SPSS 23 showed that both independent variables showed tolerance values for leadership style variables 0.999 and work discipline variables $0.999>0.10$, and VIF values for leadership style variables 1.001 and work discipline variable of $1.001<10$. This means that there are no symptoms of multicollinearity in the results of the study, in other words the regression test model is good and feasible to be used or tested. 


\subsection{Multiple Linear Regression Analysis}

Multiple Linear Regression Analysis is intended to find out how much influence the leadership style and work discipline on the performance of employees of PT. Telecommunication Indonesia, Tbk. Before the multiple linear regression test, then first will be presented result of processed regression data with SPSS 23. The result of multiple linear regression by using SPSS 23 , for independent variable (leadership style and work discipline) to dependent variable (employee performance), the regression equation that happened is as follows:

The aforementioned regression equation can be explained as follows:

1. If variable $X 1$ increases one unit assuming variable $X 2$ is fixed then $Y$ (dependent variable) will increase by 0.183 . Conversely, if variable $X 1$ has decreased one unit with assumption variable $X 2$ is fixed then $Y$ will decrease equal to 0,183 .

2. While in variable $X 2$, if one unit increases with assumption $X 1$ variable is fixed then $Y$ (dependent variable) will increase equal to 0,663. Conversely, if variable $X 2$ has decreased one unit with assumption $X 1$ variable is fixed then $Y$ will decrease equal to 0,663 .

\subsection{Hypothesis test results}

\subsubsection{Coefficient determination test results $\left(R^{2}\right)$}

The coefficient of determination is used to find out how big the independent variables have an influence on the dependent variable. Determination coefficient value used adjusted $\mathrm{R}$ square. The test is known coefficient of determination (adjusted $\mathrm{R}^{2}$ ) of 0.474 which means that variation $Y$ can be explained by the variation of the three independent variables $X 1, X 2$ of $47.4 \%$, while the rest is explained by other factors outside the model of this study.

\subsubsection{Simultaneous significance test result (Test F)}

A significant test of simultaneous or $F$-test is used to determine whether the results of the regression analysis are significant or not. Significant used is 0.05 . If the probability or significance is greater than 0.05, then Ho is accepted or Ha is rejected and if the probability or significance is less than 0.05 , then Ho is rejected and Ha is accepted. Based on the test results of model significance the value of $F_{\text {arithmetic }}$ of 65.929 is greater 
than $\mathrm{F}_{\text {table }}$ that is equal to 3.06 and the value of significance below 0.05 . Then it can be concluded that $\mathrm{H}_{1 \text { is }}$ accepted and $\mathrm{H}_{0}$ is rejected which means that the independent variable $\left(\mathrm{X}_{1}, \mathrm{X}_{2}\right)$ simultaneously or together affects the dependent variable $(\mathrm{Y})$.

\subsubsection{Partial significance test (T-Test)}

Partial or individual test is used to determine whether an independent variable has real or no effect on the dependent variable. Decision-making can be done by looking at the probability/significance, namely:

1. If the probability/significance $>0.05$ then Ho accepted and Ha rejected

2. If the probability/significance $<0.05$ then $\mathrm{Ho}$ is rejected and Ha accepted

(a) Variable $\mathrm{X}_{1}$. Test the hypothesis of the influence of leadership style on employee performance. Based on Table $4.16 t$-test results for $\mathrm{X}_{1}$ obtained $\mathrm{t}_{\text {arithmetic }}=3.029$ with a significance level of 0.003 . By using the significance limit of 0.05 and $\mathrm{df}(n-2)$, that is, 143 obtained $t_{\text {table }}$ of 1.65 . Based on the aforementioned data obtained results that $t_{\text {arithmetic }}$ larger $t_{\text {table }}$, which means $\mathrm{H}_{0}$ rejected and $\mathrm{H}_{1}$ accepted.

(b) Variable $X_{2}$. Test the hypothesis of the influence of work discipline on employee performance. Based on Table $4.16 t$-test results for $\mathrm{X}_{2}$ obtained $\mathrm{t}_{\text {arithmetic }}=10.967$ with a significance level of 0.000 . By using the significance limit of 0.05 and $\mathrm{df}(n-2)$, that is, 143 obtained $t_{\text {table }}$ of 1.65 . Based on the aforementioned data obtained results that $\mathrm{t}_{\text {arithmetic }}$ larger $\mathrm{t}_{\text {table }}$, which means $\mathrm{H}_{0}$ rejected and $\mathrm{H}_{1}$ accepted.

\section{Conclusions}

This study tries to analyze the variables related to the influence of leadership style and work discipline on employee performance at PT. Telecommunication Indonesia, Tbk DKI Jakarta. From the results of research that has been obtained from the calculation of data processing using SPSS Version 23, it can be drawn conclusion as follows:

1. There is a significant influence between leadership style and employee performance of PT. Telecommunication Indonesia, Tbk. The indicator in the leadership style that has the highest mean is in the statement 'Leader manages subordinates according to his own desires. Therefore, leaders who can motivate employees will be able to shape employee performance for the better. 
2. There is significant influence between work disciplines on employee performance of PT. Telecommunication Indonesia, Tbk. The indicator on the work discipline that has the highest mean value is in the 'Job according to ability' statement. Therefore, this indicator can improve employee performance of PT. Telecommunication Indonesia, Tbk.

3. The employee performance indicator that has the highest mean is in the statement 'giving priority to customer satisfaction in providing service'. Therefore, the employees of PT. Telecommunication Indonesia, Tbk which prioritizes good customer satisfaction in performing.

\section{References}

[1] Bangun, W. (2012). Manajemen Sumber Daya Manusia. Jakarta: Erlangga.

[2] Dessler, G. (2009). Human Resource Management. England Person.

[3] Dessler, G. (2009). Human Resource Management (Vols. Edisi ke-12). England Person.

[4] Ghozali, I. (2013). Aplikasi Analisis Multivariate dengan Program IBM SPSS. Semarang: Universitas Diponegoro.

[5] Hardian. (2015). Pengaruh Gaya Kepemimpinan Terhadap Kinerja Karyawan. Jurnal Administrasi Bisnis, vol. 10, no. 1, pp. 202-207.

[6] Hasibuan, M. (2013). Manajemen Sumber Daya Manusia (Vol. Edisi Revisi). Jakarta: Bumi Aksara.

[7] Indriani, S. (2015). "Hubungan Lingkungan Kerja, Disiplin Kerja dan Kinerja Karyawan". JMK, (17)2, 131-140

[8] Johannes, T. (2014). "Pengaruh Gaya Kepemimpinan dan Motivasi Terhadap Kinerja Karyawan". Jurnal Acta Diurn;a, (3)4, 54-64

[9] Mailiana. (2016). "Pengaruh Disiplin Kerja Terhadap Kinerja Pegawai". Jurnal Ekonomi Manajemen, (10)1, 56-64

[10] Mangkunegara. (2015, September). "Effect of Training, Competence and Discipline on Employee Performance in Company". Journal Global Conference on Bussiness and Social Science, $(15) 3,121-133$

[11] Mangkunegara, A. P. (2009). Manajemen Sumber Daya Manusia. Bandung: PT Remaja Rosdakarya.

[12] Mathis, R. L., \& John, J. (2012). Human Resource Management. Jakarta: Salemba Empat. 
[13] Mondy, W. (2008). Manajemen Sumber Daya Manusi (Vols. Edisi ke-10). Jakarta: Erlangga.

[14] Muhammad, A. (2014). "The Importance of Working Discipline to Improve Employee's". Journal BusinessManagement and Strategy, (5)2, 196-202

[15] Mulyadi, D., \& Veithzal, R. (2010). Kepemimpinan dan Perilaku Organisasi. Jakarta: Rajawali Per.

[16] Ojokku. (2012). "Impact of Leadership Style on Organizational Performace". American Journal of Bussiness and Management, (1)4, 59-66

[17] Paracha. (2012). "Impact of Leadership Style (Transformational \& Transactional Leadership) on Employee Performance and Mediating Role of Job Satisfaction". Global Journal of Management and Business Research, (12)1, 23-33

[18] Robbins, S. P., \& Judge. (2010). Perilaku Organisasi (Vols. Jilid 1-2 Edisi 12). Jakarta: Salemba Empat.

[19] Setiawan, B., \& Waridin. (2013). "Pengaruh Disiplin Kerja Karyawan dan Budaya Organisasi Terhadap Kinerja". Jurnal Ekonomi Manajemen, (2)5, 1-16

[20] Sutrisno, E. (2013). Manajemen Sumber Daya Manusia. Jakarta: Kencana Predana Media.

[21] Teddy, C. (2016). "The Influence of Leadership Style, Work Environment and Job Satisfaction of Employye Performance". International Journal Education Studies, (9) $1,123-134$

[22] Wirawan. (2009). Evaluasi Manajemen Sumber Daya Manusi. Jakarta: Salemba Empat.

[23] Zaenal, M. (2015). "The Influence of Motivation and Discipline Work Against Employee". Review Journal of European Studies, (7)12, 132-141 